\title{
MUSLIM FAIENCE FRAGMENTS FROM THE EXCAVATIONS OF THE OTTOMAN FORTRESS OF SED-ISLAM IN SOUTHERN RUSSIA (MIDDLE OF THE $17^{\mathrm{TH}}$ TILL EARLY $18^{\mathrm{TH}}$ CENTURIES)
}

\author{
Khalil, W. ${ }^{1} \&$ Gusach, I. ${ }^{2}$ \\ ${ }^{1}$ Islamic Arch. dept., Faculty of Archaeology, Fayoum Univ., Fayoum, Egypt. \\ ${ }^{2}$ Senior staff scientist of the Azov Museum-Reserve, Russia \\ E-mail:wam00@fayoum.edu.eg
}

\begin{abstract}
This article describes faience fragments, a kind of Turkish art ceramics of XVII-XVIII cc., which have been produced in the Ottoman Empire in the city of Kütahya. Fragments of those cups are found on the territory of the former Ottoman fortress of Sed-Islam situated not so far from the Nedvigovka settlement of the Miasnikovskyi district of the Rostov region (on the left bank of the river Mertvyi Donets). The authors cite the modern classification of "Turkish" ceramics stored in archaeological funds of Archaeological reserve museum "Tanais". Kütahya potters have used Chinese and local Turkish motifs for decoration of their production.
\end{abstract}

Keywords: The Ottoman Empire, Sed-Islam Fortress (so-called Lutik), Turkish painted Faience ware, Iznik, Kütahya

\section{Introduction}

Preserved till nowadays, the remnants of the Ottoman fortress of Sed-Islam (according to Russian written-sources it was called "Lutik" which means "buttercup") are located in the Southern region of the Russian Federation, not so far from the Azov Sea, on the banks of the river Mertviy Donets, $2.5 \mathrm{~km}$ away from the Nedvigovka settlement of the Rostov region. It is an archaeological site that dates from the middle of the XVII till early XVIII centuries, according to written sources [1-7], maps [8-11] and monetary material that were found by archaeologists during excavations of the fortress. Besides, Sed-Islam fortress was built by Ottomans in 1660 with two stone towers; Shakhi and Sultanije, which were built on opposite banks of the River Don, near another
Ottoman fortress of Azak (according to Russian written sources, it was called Azov). All of these stone strengthening constructions became a part of the powerful Ottoman military defensive system on the border with the Russian State. They have also been used to combat Don Cossacks, who often organized military naval campaigns in the Azov and Black seas [5-7]. Moreover, in 1696, during the Second Azov campaign of the Russian Tsar Peter I, the Turkish fortresses of Sed Islam and Azak were occupied by the Russian military forces. However, after the Prut campaign of 1711, which was unsuccessful for Russia, all of these fortresses, according to the signed peace treaty, were returned to the Turks. Newly Ottoman fortresses Sed-Islam and Azak were conquered by 
the Russian army in 1736, during the Russian-Turkish war of 1736-1739. But under the terms of the Belgrade Peace Treaty of 1739, they were blown up and almost completely destroyed in the early 1740s. Therefore, during its existence, the Ottoman fortress of Sed-Islam (as well as the fortress of Azak) survived two "Turkish" (1660-1696; 1712-1736) and two "Russian" (1696-1711; 1736-1741) periods $[2,12,13]$. It is important to mention in this context that in 1970-1973 an archaeological research was conducted by Valery Fedorovich Chesnok took place in the territory of the former Turkish Sed-Islam (Lyutik) fortress [14]. In 19931994 next to the fortress, Rostov archaeologists dug two pits under supervision of Vyacheslav Nikolayevich Kuzmin [15-
18]. All archaeological material resulting from the works of these two expeditions was deposited at the Tanais Archeological Museum-Reserve (settlement of Nedvigovka, the Rostov region, Russia). For a long time, an archeological found remained poorly studied due to the lack of specialists on the Ottoman culture. The first scientific studies of ceramic complex of Sed-Islam fortress were published only in the early 2000s [19-20].Consequently, currently specialists continue working with collections. This article is another step in studying Muslim artifacts that were found in the South of Russia. The objective of our research is to describe and classify the Ottoman painted faience vessels of the XVI-XVIII centuries discovered by archaeologists on this site.

\section{The Basic Types of the Painted Faience Crockery from the Excavations in the Ottoman Fortress of Sed-Islam (Lutik).}

Among the numerous finds of archaeologists from the Sed-Islam fortress, examples of the Turkish artistic (hand painted) faience vessels highly deserve special attention. First and foremost, the so-called "Kütahya fragments" (that unfortunately are heavily fragmented). These cups, along with other forms of vessels (jugs, vases, saucers, plates, etc.) were produced in the XVII-XVIII centuries in Kütahya (the territory of the Ottoman Empire) and were exported via trade routes to all Turkish fortresses in large numbers, even such far ones, such as Sed-Islam and Azak [21-25]. They were made by craftsmen of soft silicate molding mass of white or pinkish-cream color, referred to as "Quartz-fritta" or "one of the types of cashine" [26,27]. In the scientific literature, such crockery is known as "faience". However, some researchers believe that it would be more correct to call it "semifaience" because it is different from the faience crockery with the glaze put on top of painting (faience vessels have nontransparent or semi-transparent colorless glaze, while the semi-faience has transparent colorless glaze) [27-30]. We will not go into such details. Also, we will traditionally refer to the Turkish dishes described in this article as faience, as most researchers do of the Ottoman ceramics nowadays. Turkish artistic faience also includes another kind of painted vessel fragments that were also found during the excavation of the Ottoman fortress of Sed-Islam. It is a widely known during the rise of the Ottoman Empire, the so-called "Iznik" vessels (jars, vases, mugs, dishes, plates, etc.) produced in XVI-XVII centuries in Iznik and other ceramic centers of Anatolia (Istanbul, Kütahya, Burgas, Sivas, etc.). Imitations of Iznik painted faience pottery of Turkish production are found rather often. They are hard to be distinguished from genuine products of Iznik. Thus, all the term "Iznik faiences" is very relative. During the whole period of the archaeological investigations of Sed-Islam fortress on the Mertviy Donets river only two samples of the so-called "Iznik" faience pottery were found: a fragment of a lower part of a big dish [31] with "Abraham from Kütahya" or "Blue and white" style 
of painting ( according to Arthur Lane's classification; a fragment of a plate (or a dish) with a "Rhodos" style of painting [31]; both samples originate from the excavations of V.F. Chesnok (AMR KP $10 / 140,142)$. At the same time, many pieces of such a kind of pottery were found during the excavations of nearby located Turkish fortress of Azak [24,32$34]$, which were held at the end of XX beginning of the XXI cc. and also in other Ottoman fortresses of Black Sea region (Akkerman, Ochakov, Kaffa and Sudak) [35]. Obviously, in contrast to the military garrison of the Azak fortress, soldiers and officers of a small $(30 \times 40$ meters) fortress of Sed-Islam could not afford and enjoy so expensive "Iznik" faience vessels. However, painted porcelain vessels (jugs, plates, bottles, vases, decanters, bowls, etc.), produced in the XVII-XVIII centuries by masters of Kütahya, valued less Iznik faiences, so their cost was cheaper and were more widely distributed among the population of the Ottoman Empire. Kütahya faience fragments were especially popular due to the addiction of Ottomans to drink coffee. They are found at almost all archaeological monuments of the former Ottoman Empire [21,23,24,31,35]. French traveler of the XVIII century Charles De Pejsonel, who visited Crimea in 1755 , mentioned a big amount of fragments exported from Kütahya to Black Sea and Mediterranean Sea regions [31]. Faience cups of Kütahya attracted attention because of their refinement, lightness, brightness and originality of under glaze painting. Molding mass from which these products were manufactured, very light, almost white in color, and had no visible impurities. Crock was characterized as dense, finepored and thin. Engobe painting of such shields was not mandatory because of their light surface color. The glaze is always transparent, colorless, usually of good quality, applied in a thin layer on both surfaces of the vessel, except for the ring under pan. Size of such fragments is usually standard: cup's height - nearly $5,0 \mathrm{~cm}$; diameter at the top - 7,5-8,0 cm; thickness of walls - 0,2-0,5 cm; height of the circular under pan - 0,4-1,0 cm; diameter of the under pan - 3,0-4,0 cm. According to their shape cups are divided into two types: bell-like, fig $g_{\mathrm{s}}(1,2,3 \& 4)$ and hemispherical on low circular under pan. Both forms were borrowed from Chinese porcelain. Moreover, hemispherical form of cups is met much more often than bell-like (or "dome-like" according to Arthur Lane [31]). Additionally, 154 pieces of Kütahya fragments were found during the archaeological research on the territory of the Ottoman fortress of Sed-Islam (132 fragments from the excavations of 1970-73 B. C. and 22 fragments - from the excavations of 1993-94 B. C.).They include: 64 pieces of hemispherical cups, 10 - belllike, other cannot be characterized according to pieces left. Thus, we differ between thin-walled cups and thick ones. The major part of cups has thin walls $(0,2$ $0,3 \mathrm{~cm})$. Cups' top has a triangle or half-oval forms in section, sometimes it becomes thinner. Circular under pan is not so high, narrow. Under pan's bottom is flat or slightly sharpened. In scientific literature, faience fragments of Kütahya are classified by type of under glaze painting. Cups of Sed-Islam are characterized by two main types of paintings, which can be classified as two groups: with blue-and-white painted or painted in cobalt blue (group 1) and with polychrome painting (group 2). These are the most common types of cups with under glaze painting that are usually found on all other monuments of the so-called "Turkish time", including findings from Turkish fortress of Azak [23]. Other types of ornamentation of the fragments are very rare. 


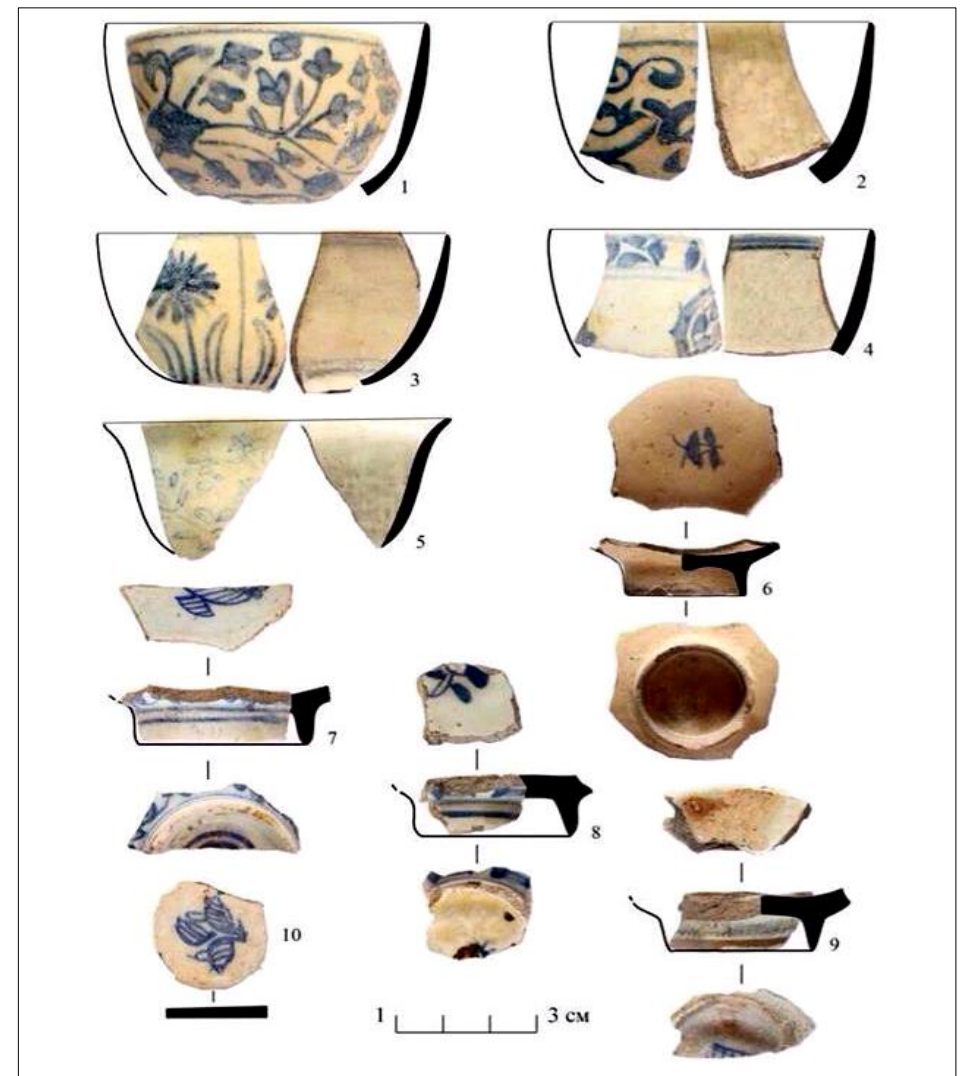

Figure (1) Shows fragments of painted coffee cups (No. 1-10-group 1) from excavations of Turkish fortress of Sed-Islam, Faience, Ottoman Empire, Kütahya (XVII-XVIII cc.)

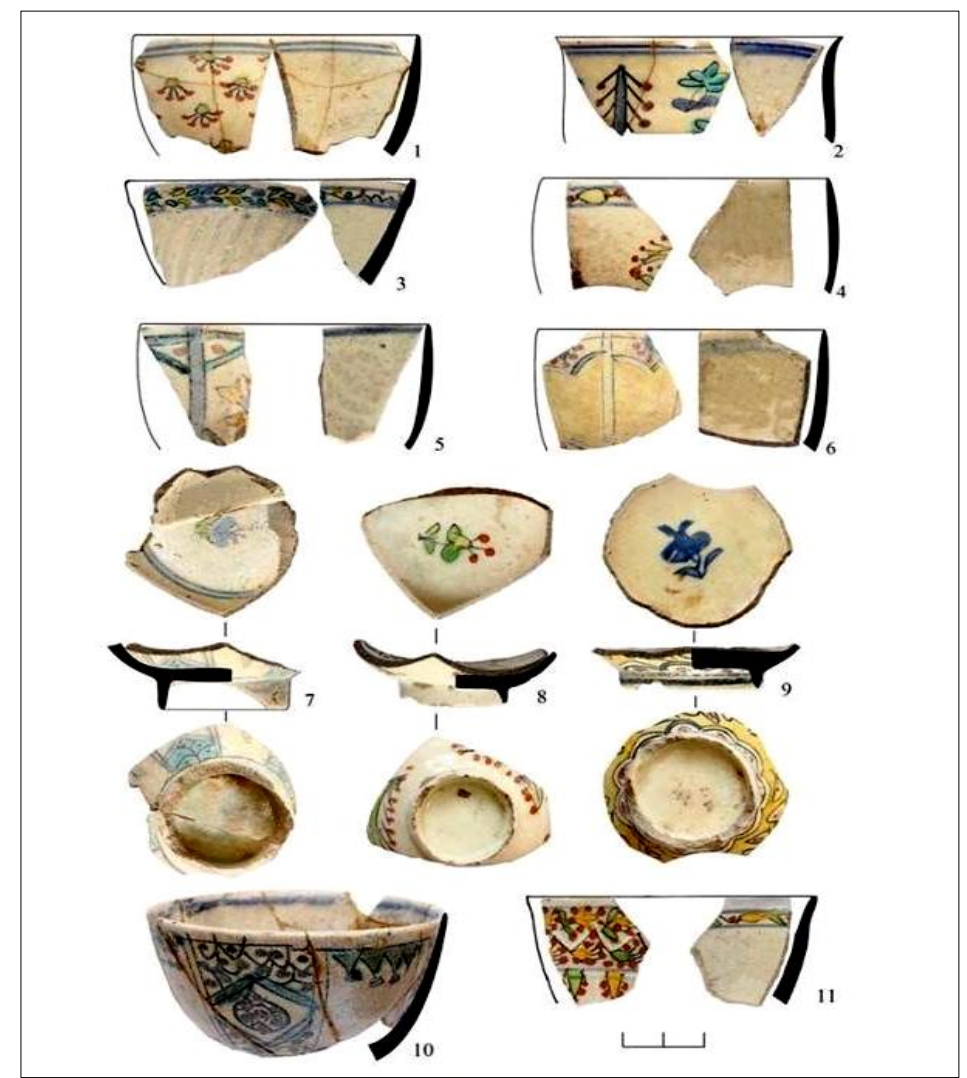

Figure (2) Shows fragments of painted coffee cups (No. 1-11-group 2) from excavations of Turkish fortress of Sed-Islam, Faience, Ottoman Empire, Kütahya (XVII-XVIII cc.) 


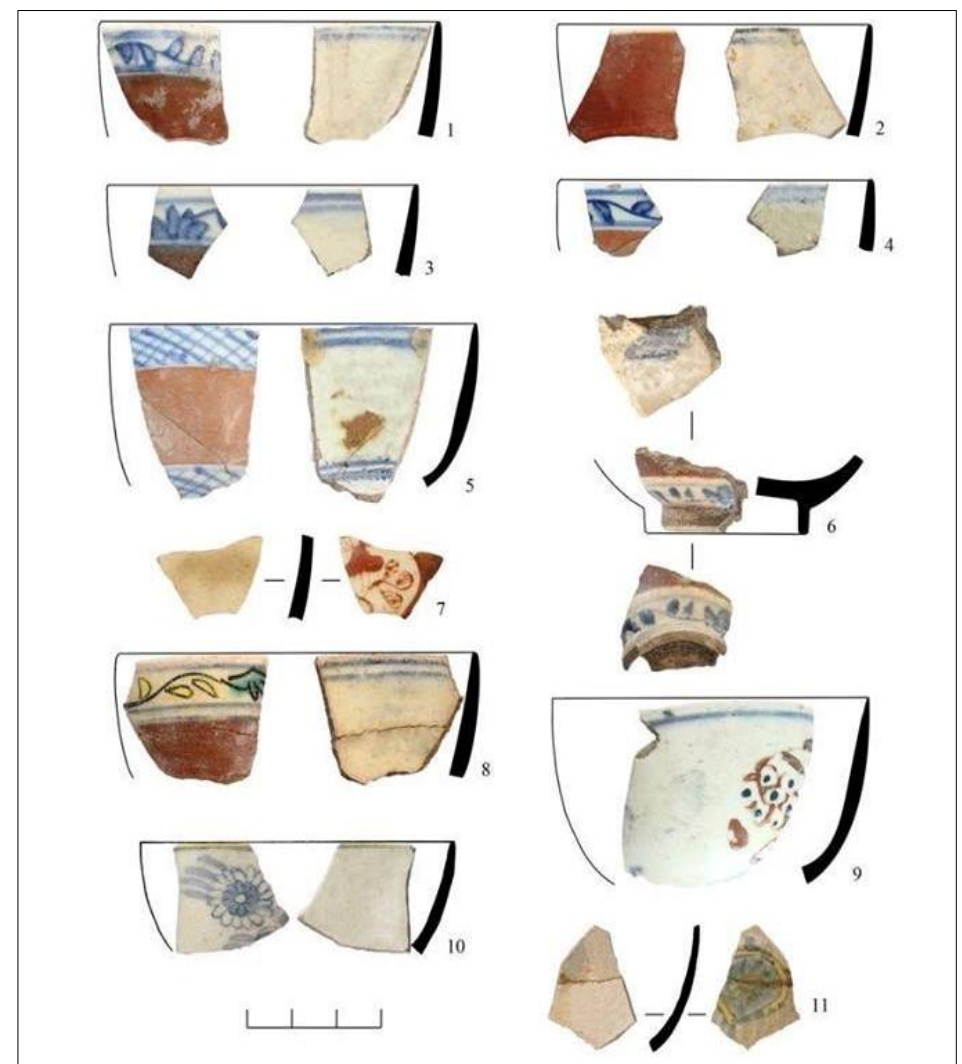

Figure (3) Shows fragments of painted coffee cups (No. 1-6-group 4, No. 7 - group 5, No. 8 - group 6, No. 9-11, - group 3) from excavations of Turkish fortress of Sed-Islam, Faience, Ottoman Empire, Kütahya (XVII-XVIII cc.)

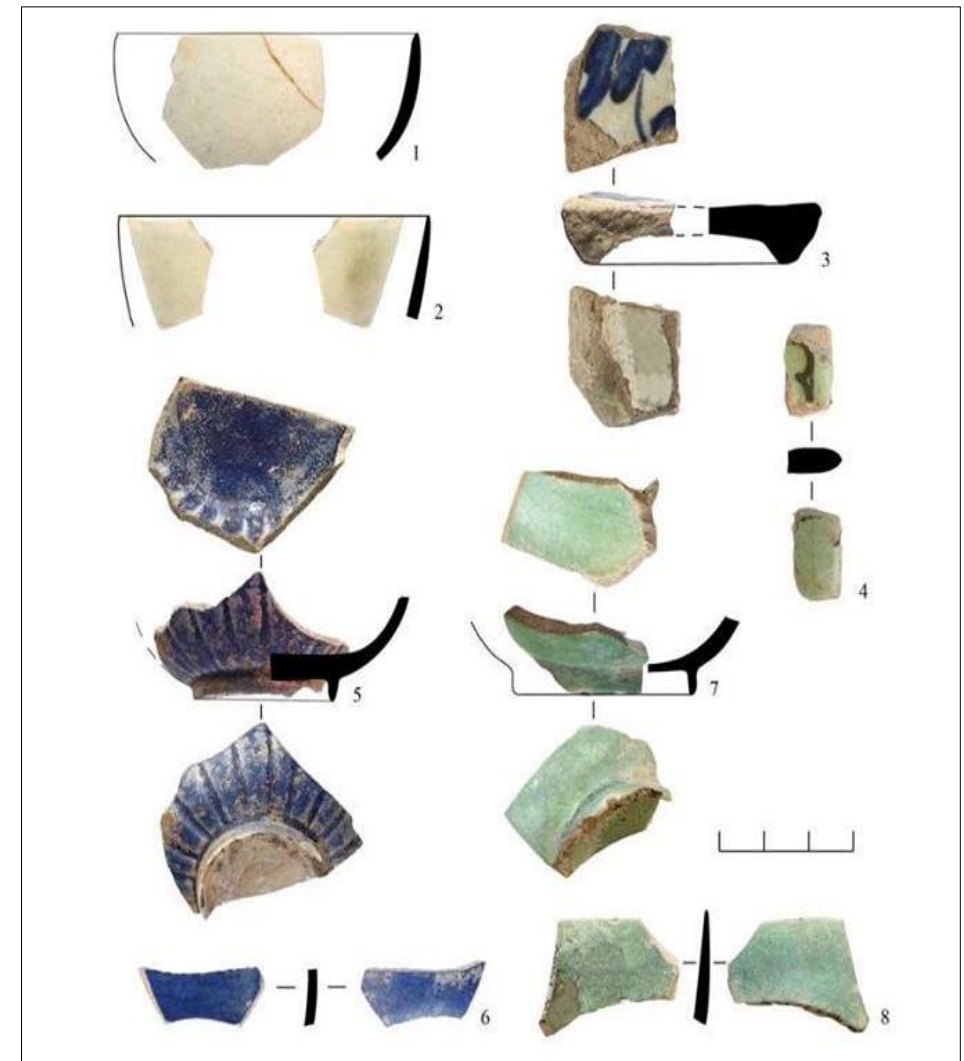

Figure (4) Shows fragments of painted coffee cups (No. 1-2-group 7, No. 5-6 - group 9, No. 7-8 group 8) and "Iznik" dishes (No. 3-4) from excavations of Turkish fortress of SedIslam, Faience, Ottoman Empire, Kütahya (XVII-XVIII cc.) Iznik (XVI-XVIII cc.) 


\subsection{Group (1) fragments with blue-and-white (cobalt) painting}

This group includes 90 fragments of cups from the excavations in fortress of Sed-Islam. The overwhelming majority of them have hemispherical shape. 62 fragments belong to thin-walled vessels, 28 to thick-walled ones. Painting is done by hand in blue (cobalt) usually on both surfaces, sometimes on only one surface (either external or internal). 36 fragments of cups are painted with cobalt two shades: light blue (the picture) and dark blue (the drawing contour). Pattern of 46 fragments of cups was made in dark blue; 8 fragments have light blue painting. Often fragments have carelessly done painting: drawing blurred outside the contour lines. Ornamental motifs fragments with under glaze painting in most cases represent the imitation of Chinese porcelain of the Ming dynasty (1368-1644): inte-rwoven stems with leaves and lotus or peony flowers, fig (1-1), thin curved bra-nches with small narrow curled leaves, fig (12) and images of leaves of a fern, small protuberances with floral sprouts with small oval leaves «growing out» of them , fig (1-5); "wheels of fire", fig (1-4). Like Chinese masters, Turkish ones often used thin concentric circles, fig (1-1,4,7,8) and narrow ornamental strips, filled with geometric shapes or "garlands" of small oval leaves, fig (1-4). Bottoms of cups inside usually have traditionally round medallion with the image of a flower or floral outlet inside, fig (1-6-8,10). Besides, Turkish motifs of painting on fragments are represented by floral-flower compositions (sometimes combined with geometrical ones): inverted images of large Tulip buds, small and large floral sockets, fig (1-1,3). Compositionally ornament can fill as all space body coverage, fig $(\mathbf{1}-1,2,5)$ and groups, fig (1-4) may be placed in the cartouches and medallions, fig (1-7) or be in vertical sectors ("arch-like" ornament) , fig (1-3). Kütahya faience cups with a similar blue-white (cobalt) painting were found during archaeological research in the fortress of Azak [23,24]. Hallmarks are occasionally found at the bottom of the Ottoman vessels (from the outside). The most common mark of Kütahya fragments of XVII-XVIII centuries is the so-called "asterisk", which originated as a result of imitation hallmarks of European porcelain and, above all, the hallmarks of Meissen which was in the form of crossed swords $[31,35]$. Astrisk-like hallmarks on Kütahya fragments are very often found in the fortress of Azak [23, 24]. Only one such hallmark was found on the fragments with blue and white ornamentation from the Sed-Islam fortress, fig (1-8). Another kind of hallmarks is represented by Chinese characters. They are less common than astrisk-like marks and imitate stamps on the Ming porcelain. Only one blue and white coffee cup with a hallmark resem-bling a Chinese character or a diamond (it did not remain in full) was found in the fortress on Mertvyj Donets, fig (1-9).

\subsection{Group (2) fragments with polychrome ornamentation}

Kütahyan potters mastered polychrome style of faience ornamentation and started to use it widely in the first half of the $18^{\text {th }}$ century. The vessels were decorated with bright colors: yellow, red, blue and green. Black paint was usually applied for drawing contours and for hallmarks. Original bright small floral and geometric patterns of the Kütahyan crockery made it especially colorful and distinctive. Thanks to them, this Ottoman crockery was easily recognizable ant popular among the customers. The shape of faience Kütahyan fragments remained the same; hemispheric and bell-like. Among the fragments with polychrome painting found during excavations in the fortress of Sed-Islam (38 fragments in total) cups of hemispherical shape prevail, fig (2-1,36,10). Bell-like cups are rare, fig $(\mathbf{2}-2,11)$. Almost all cups are thin-walled. The ornamentation is usually applied to both surfaces of these cups. The scenes depicted in polychrome manner on the Kütahya cups is a "mixture" of the Chinese Ming decorative elements (XIV-XVII centuries) 
with Ottoman elements of XVII-XVIII centuries, with the latter clearly prevailing. They include the image of famous Ming lotuses, peonies, chrysanthemums, fig (29,10) and a variety of "Turkish" flowers (especially the famous Ottoman tulips), densely decorated with red dots, fig (2$1,2,4,5,7,8,11)$. The Turkish ornamentations often include small floral rosettes, thin curved stalks with oval leaves, fig (2$1,7,8)$ and the so-called floral "garlands", fig $(2-3,4,11)$. Sometimes the images of trees, long narrow leaves «saz» and geometric shapes are also found. Compositionally the ornamentation can fill all the free surface of a cup, fig $(\mathbf{2}-1,2,9)$, or placed in small floral groups, fig $(\mathbf{2}-4,8,11)$, or placed in vertical narrow sectors ("arched" ornamentation), fig $(2-9,10)$. The restorers managed to restore the upper part of the coffee cup of fragments with polychrome ornamentation (AMRT KP 10/137), which clearly demonstrates such "sectorial" ornamental composition, fig (2-10). Design of Turkish fragments with polychrome painting, like cups with blue-and-white painting, have concentric circles that are blue or black, sometimes red, fig (2-1,2,5$7,10)$. Concentric circle on the bottom often acted as a round medallion in the center of which a polychrome or bluewhite image of flower is panted, fig (22,7). In addition to the concentric circles

\subsection{Group (3) fragments with bichrome ornamentation}

This style of painting, according to a small number of finds, is very rare. Its distinguishing feature is the presence of additional colors (yellow or brown) in well-known blue-and-white (cobalt) painting scheme. There are only three pieces of cups with two-colored painting from Sed-Islam fortress: two with blue-yellow painted (AMZT SAF 35/228, 229), and one with blue and brown painted (AMRT KP 10/ 105). Two fragments of fragments with blue-yellow painted originate from the excavations of 1993 may refer to a thin-

\subsection{Group (4) fragments with blue-and-white painting and brown cover}

This kind of Ottoman fragments is an imitation of painted Chinese porcelain on the cups with polychrome painting, there are narrow ornamental stripes of alternating yellow and green oval leaves and red dots connected by a thin black wavy lines, fig $(\mathbf{2}-3,4,11)$. There are also other varieties of ornamental stripes. It is well-known that the outer surface of the Kütahya fragments with polychrome painting in the XVIII century were additionally decorated with relief ornament in the form of fine rhomboid mesh, oblique patterns, flower petals, etc. [23,24,35]. Two fragments of fragments of the $2^{\text {nd }}$ group from the Ottoman fortress of SedIslam have some traces of such relief decorations. In the first case, it is a lotus bud or petals of a tulip convex-triangular shape on top of the bell-like cup, fig (2-11). In the second case, it is frequent, narrow, deep and vertical with a slight tilt to the right zones on a hemispherical cup that simulate numerous narrow long flower petals of chrysanthemum, fig (2-2,3). Such relief flower image (mostly tulip buds) is often found in art ceramics of the Ottomans (e.g. Turkish tobacco clay pipes of XVII-XVIII centuries) [24]. We haven't still met hallmarks on the bottoms of fragments with polychrome painting from Sed-Islam fortress. However, they are found at Kütahya fragments from the excavations in other Ottoman fortresses $[35,36]$.

walled cup. Top of one fragment is marked with the yellow color, fig (3-10), another one's space between two contour lines if filled by the so-called "wheels of fire", fig (3-11). Form of this cup is hemispherical. Another fragment of Kütahya hemispherical faience cup from the fortress of Sed-Islam was decorated with floral-geometric patterns and blue and brown color. Main decoration motifs were thin sprouts, twisted in the spiral and with small leaves and large floral rosettes at the ends, fig (3-9).

cups of Qin dynasty of emperor Kangxi times (1662-1722). Faience pottery of 
Kangxi era, decorated with under glaze blue-and-white painted and covered with brown glaze, in the late XVII ${ }^{\text {th }}$ and early $\mathrm{XVIII}^{\text {th }} \mathrm{cc}$. gained great popularity among collectors from Europe and was especially popular in Germany, England, France and Holland. In the international market, brown glaze of Chinese porcelain was called "the Batavian paint" (according Batavia, the Dutch name of Jakarta, capital of Indonesia which was a Dutch possession in the Maldivian archipelago on the coast of Java since XVII century and belonged to the famous East India trading company. Batavia traders brought porcelain from China, and then moved it to Europe). Chinese masters made coffee sets especially for Turkish buyers: cups with saucers, covered with blue-and-white (cobalt) floralgeometric patterns in combination with brown glaze covering of different shades. Iron acted here as a stain. This popular faience of not so high quality was produced in Chinese provinces in quite large quantities and was exported for sale in the Ottoman Empire. It was also found at the excavations of fortresses of Sed-Islam and Azak (fragments of cups and saucers) [24]. Masters of Kütahya, watc-hing the increased demand for Chinese porcelain cups, learned to make similar ones, made of faience. Among Archaeological artifacts from Sed-Islam fortress, there are 10 fragments of Kütahya fragments, decorated in the same manner as Chinese porcelain cups of Kangxi times, fig (3-1-6). "Chinese" brown glaze effect was achieved by Turkish masters by pouring the surface of faience cups with brown stain and coating the top with transparent colorless glaze of good quality. Blue-and-white painting, as before, was performed by two shades of cobalt light-blue (figure) and dark blue (outline). The motives of the paintings: horizontal ornamental stripes of thin curved sprouts with small oval leaves, fig $(3-1,4,6)$ and flower half-rosettes (lotus), fig (3-3). Space on the body of cups between ribs with blue-and-white painted covered with brown paint, imitating a brown Chinese glaze. Fragments of cups, similar to those, were found in the Turkish fortress of Azak [23]. One of the most popular elements of internal blue-and-white decoration of ornamental stripes of coffee cup simulating porcelain of Kangxi era was the so-called "rhombic grid", fig (3-5). The space between the two blue-and-white stripes of the "rhombic grid" was covered with the brown paint, pseudo-glaze. Fragments of faience fragments that imitated Chinese porcelain with similar paintings were found during the excavations in Azak [24]. Among the archeological findings of the $1970_{s}$ that originate from the fortress of Sed-Islam is also a fragment of the hemispherical Kütahya coffee cup, the outer surface of which is covered with the brown paint (except top), without blueand-white painting (AMRT KP 10/101), fig (3-2). Similar cups are also found in Azak. On the Kütahya imitations of Chinese porcelain of Kangxi era there are also images of a flower or floral outlet in the center of a circular medallion at the bottom, fig (3-6).

\subsection{Group (5) fragments with brown cover and brown painting in the tec- hnique of "reserve" placed inside the cartouches}

As a group, we also should allocate only a fragment of Kütahya faience cup from the excavations of Sed-Islam fortress which painted with brown in the technique of "reserve" inside big rounded cartouches placed on brown colored field. Ornament is floral in the form of thin curved sprout with small oval leaves filled with oblique hatching (veinlet of a leaf) with trefoil on the end, fig (3-7). Painting is done gently and gracefully: line-thin, not blurry, hatching within the contours. The inner surface of the cup is covered with a transparent colorless glaze (AMRT KP 10/135). Fragment of Chinese porcelain cup with similar decor is found during the excavations in the Turkish fortress of Akkerman in Ukraine [35]. 


\subsection{Group (6) fragments with polychrome painting and a brown cover}

Painting on the hemispherical coffee cup, only a fragment of which has been discovered during the research of fortress of Sed-Islam (AMRT KP 10/106), is a compound of two motives: "Chinese" (Kangxi era) and "Turkish" (late Kütahya). Surface of the cup (directly under the top) is decorated with a narrow ornamental belt with polychrome painting in the form of a thin, curved black sprout with small yellow oval leaves. Sprout is "interrupted" by a picture of green "bush" with black outline. Belt is limited with thin blue lines, placed above and below it. This is a typical
Kütahya motif of polychrome painting of the first half of the XVIII century. Below the "Turkish" ornamental zone body is covered with brown paint, simulating the "Batavian ink" of Chinese porcelain vessels of Kangxi era. Here we can see the invention of Ottoman potters, a new technique of faience vessels decoration, which combines local traditions with the traditions of the Middle Kingdom, fig (3-8). Faience fragments, belonging to the group 6 , are also found in the archaeological material of other Ottoman fortresses of the Black Sea region [35].

\subsection{Group (7) fragments without painting}

This group includes six fragments of Kütahya fragments from Sed-Islam fortress, which do not have any traces of painting. Two of them are fragments of the vessel tops with part of body of hemispherical cup (AMRT KP 10/86; KP 10/87), fig (4-1,2) while the rest are fragments of body. Such fragments of faience cups without painting were met by us for the first time. They were not found in fortress of Azak, but we find that there are findings of Chinese porcelain cups without painting. Chinese porcelain vessels without painting were also found on the ship that sank after a shipwreck in 1690 not so far from the coast of Vietnam, on its way to Batavia and has a consignment for the German market on

\subsection{Group (8) fragments with green cover}

Finds of faience fragments with a coating of green paint under colorless transparent glaze on both surfaces are very rare at archaeological sites of "Turkish time". There is only one piece of this cup, originating from excavations 1962 years in Azak [23]. During archae-ological researches of the Ottoman fortress of SedIslam, three pieces of such Kütahya faience cups with green cover were found (AMRT KP 10/138; KP 10/139; KP

\subsection{Group (9) fragments with blue cover}

It should be noted that two pieces of Kütahya fragments with blue (cobalt) under glaze covering originating from the board. There is information that, Chinese porcelain without the original painting porcelain has been produced as stencil, designed for painting of the Eur-opean masters on their "flavor and color" when over glaze ornament entered European fashion in the XVIII century. The practice of selling the so-called "semi-finished" porcelain has not been so rare during Kangxi era and Turkish artisans, sometimes also produced faience copy of Chinese porcelain "samples" without painting for their subsequent sales on the international market. According to another version, Turkish faience cups without painting imitated Chinese white porcelain (without painting) produced in Dehua pottery workshops dated the epoch of Emperor Kangxi.

203/6). Two of them are fragments of the top with part of the wall of hemispherical cups, and the third one is a low, narrow annular cylindrical bottom, obvious from the same hemispherical cups, fig (4$7,8)$. These cups seem to imitate Chinese porcelain of the era of Emperor Kangxi with monochrome glazes, including glaze of bright green colors ("Moss" color), which appeared as a result of additives of copper oxides.

excavations of the Ottoman fortress of Sed-Islam, were by the authors of this article for the first time. The first fragment is a 
part of a body, both surfaces of which are marked with dark blue paint. Paint is covered with a colorless transparent glaze. The glaze has a good quality and is marked on the surface with a very thin layer, almost merging over with the same thin colorful layer (AMRT KP 10/94), fig (4-6). The second fragment is a bottom part of the pallet body of a cup with relief (corrugated) walls. The bottom is flat, smooth, thick and on its outer surface there are traces (technological marks) of a form - thin carved circle and hemispherical bulge at the center. Circular bottom is low, narrow,

\section{Discussion and Conclusions}

Summing up all what have been written above, the following should be noted: 1) Turkish garrison of Sed-Islam fortress (Lutik) during its stay in it (1660-1669 and 1712-1736) in addition to the massive irrigation and glazed ceramics by here from different parts of the Ottoman Empire, also enjoyed art faiences from Asia Minor, and foremost, of course, Kütahya painted coffee cups. According to rather large number of fragments of these cups, (more than 150 pieces) were found during studies of the monument in the 1970's and 1990's by archaeological exp-editions of the Museum-Reserve "Tanais", faience pottery produced in Kütahya in the XVIIXVIII centuries was easy, elegant, bright and had an original painting and was demanded among the population. Apparently, low price for Kütahya products promoted their rapid spread by trade routes in all directions. This does not refer to "Iznik" faience of XVI-XVII centuries, which valued more than Kütahya ceramics. Also, their cost is more expensive and that's why they are not found anywhere. For example, in the fortress of Sed-Islam during all years of excavations, there were found only two pieces of "Iznik" faience vessels; a dish and a plate (?). 2) Range of Kütahya coffee cups that were brought to Sed-Islam fortress was very wide as demonstrated by analysis of their surviving fragments found during archaeological research of the monument. Despite a stable and cylindrical. Both surfaces of the vessel (except the outside of the circular bottom) are marked with dark-blue (cobalt) paint. This accumulation of paint is visible in the recesses on the surfaces of the cup. Glaze is a clear, colorless, it has a relatively good quality, completely covers the surface of the cup with a very thin layer (AMRT KP 10/93), fig (4-5). Here we have an imitation of Chinese porcelain of Kangxi era with monochrome glazes, among which, as known, there are bowls with corrugated walls.

form cups, hemispherical or bell-like one, painting and decoration options amaze with their variety. Masters of Kütahya developed several schemes for decorations of their products using in the Oriental (Chinese) and local (Turkish) ornamental motifs. The most popular painting schemes, as we discovered, were "blue-white" (imported from China) and "polychrome" ("Turkish") ones. All studied faience coffee cups (or their fragments) from the fortress of Sed-Islam, depending on the type of painting and design surfaces were classified into one of nine selected groups with a direct analogy in materials from the fortress of Azak. The exceptions were: Group 3 ("Coffee cups with bichrome painting"), Group 7 ("Coffee cups without painting") and Group 9 ("Coffee cups with blue cover"), were met by authors on mon-uments of "Turkish time" Priazovie region for the first time. These cups are an imitation of Chinese porcelain of the Qing dynasty of emperor Kangxi times (1662-1722). According to our observations, Kütahya coffee cups with green coating on both surfaces (Group 8) are very rare. 3) Special interest is caused by the only fragment of coffee cup, related to Group 6 ("Coffee cups with polychrome painting and brown cover"), which very ingeniously combines two styles of painting; the "Chin-ese" (Kangxi era) and the "Turkish" (Late Kütahya). This style of ornamentation shows that 
Ottoman masters went far more than "blind" imitation of oriental patterns in paintings by inventing a new generic scheme of faience decoration. The same thing could be probably said about relief images on painted vessels from Kütahya. In addition to the well-known "rhomb- shaped" mesh on coffee cups from Kütahya, sometimes there are reliefs of buds tulips (lotuses) and chrysanthemum petals, such as those that are available on the Turkish smoking clay tubes of "flower" types dated the end of XVII-early XVIII centuries.

\section{List of Abbreviations}

- AMR - $\underline{\text { Azov }}$ Museum- $\underline{\text { Reserve }}$

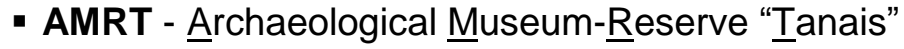

- AMRT AB - Archaeological Museum-Reserve "Tanais". Accession Book.

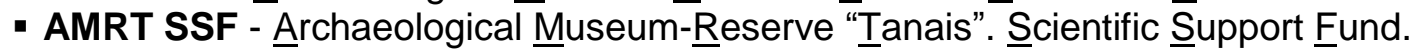

- LSU - Leningrad State University

- RSMHA - Russian $\underline{\text { State }}$ Military and $\underline{H}$ istorical Archive

- SA - Soviet Archaeology

\section{References}

[1] Рубанъ, В., (1773). The military campaign of boyar Alexey Semenovich Shein, warlord of the large regiment, to Azov, its occupation and lutik invasion, Типография морского кадетского корпуса, Санкт-Петербург.

[2] Ласковский, Ф., (1861). Proceedings for the history of engineering in Russia, Ч. II. Типография Императорской академии наук, Санкт-Петербург.

[3] Ласковский, Ф., (1865). Proceedings for the history of engineering in Russia. Ч. III. Типография Императорской академии наук, Санкт-Петербург.

[4] Don cases, (1898). T. XVIII. Кн. 1. Издательство Археологической комиссии, Санкт-Петербург.

[5] Don cases, (1917). T. XXXIV. Кн. 5. Типография министерства земледелия, Петроградъ.

[6] Сухоруков, В., (2001). Historical description of the land of the don Cossacks, Издательство ГинГо, Ростов-на-Дону.

[7] Челеби, Э., (1979). Book of the journey, (Extract from the writings of Turkish traveler of the XVII century), Вып. 2. Издательство «Наука», Москва.

[8] RSMHA, ф.349, оп.19, д.1733; ф. 422, оп.1, д.3; ф.846, оп.16, д.21307-2.

[9] Крюйс К., (1699). New drawing book containing the great river don or Tanais... (Атлас К. Крюйса), Лист 27, Издательство Генриха Донкера, Амстердам.
[10] Устрялов, Н., (1858). Maps, plans and images for the first three volumes of the history of peter the great reign. Приложения №12 к Т.II и Т.III. Типография II-го Отделения Собственной Е.И.В, Канцелярии 18581863 г, Санкт-Петербург.

[11] Ласковский, Ф., (1866). Maps, plans and drawings for the history of engineering in Russia, к III части, л.67, изобр. 8-14, Типография Императорской академии наук. Санкт-Петербург.

[12] Acts that refer to the history of the don republic, Collected by A.A., Lishin, (1891). T.I. №46. Издание Областного Правления Войска Донского, Новочеркасск.

[13] Чеснок, В., (1988). The lutik fortress (XVII-XVIII cc.), Известия РОМК, Вып.5, Ростов-на-Дону, Ростовское книжное издательство.

[14] Чеснок, В., (1970). Album of illustrations to the report about excavations in the lutik fortress in summer of 1970, Недвиговка. Архив, АМЗТ.

[15] Кузьмин, В., (1994). Report about excavations of the lutik fortress in July of 1993, Недвиговка. Архив АМЗ «Танаис».

[16] Кузьмин, В., (1994). Album of illustrations to the report about excavations in the lutik fortress in July of 1993, Недвиговка, Архив АМЗТ. 
[17] Кузьмин, В., (1996). Report about excavations of the lutik fortress in July of 1994 (handwritten), Недвиговка. Архив АМЗТ.

[18] Кузьмин, В., (1996). Album of illustrations to the report about excavations in the lutik fortress in July of 1994, Недвиговка, Архив АМЗТ.

[19] Волков, И., (2005). The Lutik-SedIslam fortress (the preliminary message and ceramics complex), Поливная керамика средиземноморья и Причерноморья X-XVIII вв, Vol. 1, pp: 482-492.

[20] Гусач, И., (2012). Kütahya coffee cups from excavations of Lutik (Sed-Islam) fortress, Вестник Танаиса, Vol. 3, pp: 114-139.

[21] Волков, И., (1998). Closed complex of Turkish period (1641-?) from Azov, Историко-культурные связи Причерноморья и Средиземноморья X-XVIII вв. по материалам поливной керамики, Vol. 1, pp: 64-68.

[22] Волков, И., (2006). Closed complex of Turkish times from Azov, Историкоархеологические исследования в Азове и на Нижнем Дону, Vol. 21, pp: 473-497.

[23] Гусач, И., (2005). Turkish faiences of the XVIII. Поливная керамика Средиземноморья и Причерноморья X-XVIII вв, Vol. 1, pp: 476-481.

[24] Гусач, И., (2006). Archaeological investigations in the territory of the Turk fortress Azak, Историко-археологические исследования в Азове и на Нижнем Дону, Vol. 21, pp: 127-141.

[25] Гусач, И., (2007). Minor Asian glazed pottery of XV-XVIII cc. from excavations of the Turkish fortress of Azak, Поливная керамика Восточной Евpопь, Причерноморья и Средиземноморья в X-XVIII вв, Vol. 2, pp: 47-55
[26] Mason, R. \& Keall, E., (1991). The Abbasid glazed wares of Siraf and the Barsa connection: petrographic analysis, «Iran», Vol. 29, pp: 51-66

[27] Коваль, В., (1997). Eastern pottery in medieval Moscow (the experience of systematization), $S A$, Vol. 2, pp: 104-122.

[28] Kубе, А., (1923). History of faience. Р.С.Ф.С.Р. Государственное издательство. Берлин.

[29] Кверфельдт, Э., (1947). Pottery of the Near East. Государственный Эрмитаж, Ленинград.

[30] Гарбузова, В., (1958). Extract from the history of the production of Minor Asian faiences in XIII-XIX cс, Ученье записки ЛГУ, Vol., 7, pp: 21-40.

[31] Lane, A., (1957). Later Islamic pottery, Faber and Faber, London.

[32] Казакова, Л., (1962). Report about investigations, held by Azov historical and archaeological museum during monitoring of excavation works in Azov in September 1961, Азов, Архив AM3.

[33] Гусач, И., (2005). Iznik semi-faiences from the Turksih fortress of Azov, Археологические записки, Vol. 4, pp: 137-144.

[34] Гусач, И., (2007). Painted Iznik semifaiences in the Turkish fortress of Azov, Средневековые древности Дона, Vol. 2, pp: 345-349.

[35] Біляєва, С., (2012). Slavic and Turk worlds in Ukraine. 3 iсторії взаємин y XIII-XVIII cm, Университет «Украина», Київ.

[36] Станчева, М., (1960). Turkish faience from Sophia, Известия на Археологическия Институт, Vol. 3, pp: 114-144. 